\title{
Existential, Instrumental and Cyber Spaces as Ontological Modi of Human Being
}

\author{
Lubov E. Motorina* \\ lubov-motorina@yandex.ru \\ https://orcid.org/0000-0002-4441-7452 \\ Veronica M. Sytnik** \\ sytnikvm@gmail.com \\ https://orcid.org/0000-0002-3451-7353
}

\author{
https://doi.org/10.31192/np.18.3.4 \\ UDK / UDC: 004.946(1):111.1 \\ Prethodno priopćenje / \\ Preliminary communication \\ Primljeno / Received: \\ 5. lipnja 2020. / Jun 5, 2020 \\ Prihvaćeno / Accepted: \\ 6. kolovoza 2020. / Aug 6, 2020
}

Context and relevance of the research: the task of developing a general theoretical basis and methodology of ontological problems of interaction and interrelation of the Internet space and the physical world comes forward with the formation of the virtual computer environment determined both by the presence of a human being in computer network and presence of computer network in the life world of the human being. Virtual reality, even in its current state, is already widely recognized and described in academic sources. There are prospects of its application in medicine, education, professional training, space, military, art, automotive industry, shipbuilding, trade, leisure, consulting assistance to population, administration, and other spheres of management. According to academic forecasts, intensive, large-scale, multidirectional development of virtual computer environment will continue in the $21^{\text {st }}$ century. The purpose of the study is to carry out a systematic analysis of the concepts: existential space, instrumental space and cyberspace in their interrelationship and interaction; to propose the author's definition of existential space as a methodological construction for the study of its ontological modi: instrumental space and cyberspace; to define the ontological characteristics of instrumental space and cyberspace, their common features (connection) and distinction; to reveal features of existential immersion of a person into virtual computer reality - the process of emotional perception of existence in the information field - an artificially created world of 'people and things,' as well as subjective-personal effects accompanying this process. The

\footnotetext{
* Lubov E. Motorina, PhD, Professor, National Research University, Philosophy Department at Moscow Aviation Institute, A-80, ГСП-3, 4 Volokolamskoe shosse, 125993 Moscow, Russia.

**Veronica M. Sytnik. Assis. Prof., National Research University, Philosophy Department at Moscow Aviation Institute, A-80, ГСП-3, 4 Volokolamskoe shosse, 125993 Moscow, Russia.
} 
methodology used: $M$. Heidegger's Dasein analytics, D. Ihde's instrumental realism, systems-based approach, comparative analysis. Key findings: the creation of cyberspace and computer virtual reality has unveiled a new stage in the formation of existential experience and project as a system of information technology and socio-psychological competencies. There is a necessity in the system-based elaboration of conceptual and categorical apparatus. The researcher will use it to describe the ontological modi of both existing and a new (computer virtual) reality and their interconnection.

Key words: computer virtual reality, cyberspace, Enframing (Gestell), existential experience, existential project, instrument, ontology, technology.

\section{Introduction}

Radical changes occurring in all spheres of life of a modern man, particularly in the creation of high information technologies, have accelerated the development of technogenic civilization. Personal transformative activity in constructing the world and self has reached a level that can exceed the existential possibilities of a human. Hence, the ontological problematics acquires a particular urgency, for it calls to answer several pressing questions: Will human being remain that which always understands itself from its existence, the possibility of it being itself or not itself? Will a person be able to confirm his 'ability to stand' and to stand open inside the openness of being? What will a modern person ask, referring to being, and will he ask the world the right questions in order to hear answers that are self-saving? The purpose of the article is to consider existential space as an initial integral structure, authentic to human being as a methodological construction for the research of its ontological modi: instrumental space and cyberspace; to offer the author's definition of existential space; to reveal ontological traits of instrumental space and cyberspace; to analyze the relationship between existential space, instrumental space, and cyberspace under new information-technological conditions.

\section{Existential Space as the Original Integral Ontological Structure of Human Being}

When identifying the structure of existential space as the initial basis of all ontological modi of human being, we will proceed from the fundamental ontology of Martin Heidegger. Heidegger defined human being (Dasein) as the only kind of being able to question, interpret, search for meaning, and get involved in the world of everyday work and action. The existential being of man, 
according to Heidegger, manifests itself holistically in the modus of individuality (self) and every time resists its dissolution in facelessness (das Man). Exactly a person as an individual, asking, comprehending, searching, arguing, doubting, making choices, creates both the world of culture ('the second nature') and their destiny. Awareness of one's individuality is a human's real being in its integrity, meaningfulness, and realization. Reasoning from this, we consider the personal component of existential space as the main constitutive element of its other ontological structures. To those, we count fundamental human attitudes to the world. ${ }^{1}$ By the fundamental attitudes of man to the world, we understand the attitude of man to things, defining him as an objective being ${ }^{2}$; the attitude to another person is social being, and the attitude of a person to the transcendental entities: nature, God, the Absolute. Heidegger called the coherence of these structures' existentiality. ${ }^{3}$

Thus, existential space, as the basic structure of human existence, is an ontological structure that is authentic to the human being, generated and conditioned by care. Care, according to Heidegger, is the initial structural integrity, 'existential-a priori' underlying all multivariance of human being. Care is the criterion that divides human being into authentic and inauthentic, owned and un-owned.

The main content of existential space is the existential experience (being in actuality) and existential project (being in potentiality). Let us analyze the approaches of contemporary authors to the problems associated with the study of existential space and existential experience. The central contradiction, which the researchers of this problem note, is that, on the one hand, existence, in their opinion, is connected with individuality, originality, specificity. On the other side, existence as ontological, essentially forming a structure of the human being, is integrity (unity). Yu. S. Appolonova formulates this contradiction as onto-existential antinomy of one and only, i.e., in her opinion, to exist as the human being means to be the one and only simultaneously. ${ }^{4}$ At the same time, the single existence is considered as a result of the "holistic experience by a specific person of his own being in the world in a certain situation." That is, it comes down to experience as the only existential. Allocation of experience as

${ }^{1}$ Lubov E. MOTORINA, Veronica M. SYTNIK, Fundamental'nye otnosheniya cheloveka k miru [The Fundamental Attitudes of Man to the World], Voprosy filosofii, 3 (2017) 69-79.

${ }^{2}$ Lubov E. MOTORINA, Veronica M. SYTNIK, Man's Attitude to Things: Objective Being, Nova prisutnost, 17 (2019) 1, 163-173.

${ }^{3}$ Martin HEIDEGGER, Being and Time, Translated by Joan Stambaugh, NY, State University of New York Press, 1996, 11.

4 Yuliya S. APPOLONOVA, Ekzistencial'nyj opyt kak predposylka trancendirovaniya [Existential Experience as a Precondition of Transcendence], Vestnik CHelyabinskogo gosudarstvennogo universiteta, 9(419) (2018) 38-45.

${ }^{5}$ Yuliya S. APPOLONOVA, Transcendirovanie kak metafizicheskij aspekt sushchestvovaniya cheloveka [Transcending as a Metaphysical Aspect of Human Existence], Thesis Abstract, Barnaul, 2019, 11. 
the main, and sometimes the single, component of the existential experience and space, represents a rather common point of view. Thus, I.P. Cherednichenko notes that when it comes to existential space, one has to talk not about living but the experience, because everything that happens in existential space is experienced as emotionally as possible. ${ }^{6}$ Alongside, Cherednichenko defines it as "the space of genuine human existence, the point of reference in which is the innermost 'Self' as the value core of the personality" , that is, the researcher connects existential space with the personality component. Also, N.A. Kasavina investigates the personal basis of existential experience. In her opinion, it "acts as a personal history of existence, in which an individual clarifies for themselves meaningful values." ${ }^{8}$ Kasavina proposes to investigate existential experience as a culturally conditioned, meaningful search. ${ }^{9}$ She is critical to the point of view of another author, T.A. Kuzmina, who, on the contrary, denies any cultural conditioning of existential experience. Strengthening the accent of individuality, uniqueness, freedom, openness of existence, Kuzmina writes that existential experience is a holistic personal reaction but emphasizes that it is not conditioned by any cultural and social attitudes and norms. ${ }^{10}$

As we may see, there is no agreement yet, and discussions continue among researchers on the question of socio-cultural conditionality of existential experience. Despite the disagreements in approaches to the study, it is possible to identify common points of convergence.

First of all, all authors emphasize experience, emotions, and the related processes of understanding, structuring, and reflection. Secondly, researchers stress the personal basis of existential experience as a carrier of qualities of individuality, originality, openness, freedom, creativity, ability to reflect, understand, and search for the meaning of life.

Thus, starting from M. Heidegger's fundamental ontology and the conclusions obtained from the analysis of contemporary sources, we propose the author's definition of existential space as the initial ontological integral structure of human being, conditioned by care and including the fundamental human attitudes to the world of things, to the world of another person, to the world of the Absolute and themselves. The content of existential space is the existential experience in its integral and singular statuses. Any singular is involved in the integrity, and the integrity is present in the singular as meaningful and value

${ }^{6}$ Irina P. CHEREDNICHENKO, Perezhivanie v ekzistencial'nom prostranstve [Experience in Existential Space], Gumanitarnyj vektor, 2(22) (2010) 189.

7 Ibidem.

${ }^{8}$ Nadezhda A. KASAVINA, Ekzistencial'nyj opyt: perezhivanie i stanovlenie struktury [Existential Experience: Experiencing the Path and Becoming a Structure], Voprosy filosofii, 7 (2013) 63.

9 Nadezhda A. KASAVINA, Ekzistencial'nyj opyt kak fenomen kul'tury [Existential Experience as a Phenomenon of Culture], Voprosy filosofii, 10 (2014) 46.

${ }^{10}$ Tamara A. KUZMINA, Ekzistencial'nyj opyt i filosofiya [Existential Experience and Philosophy], Voprosy filosofii, 7, 2007, 22. 
orientations of an individual in the structure of existential project. The term 'space' in combination with the term 'existentiality' implicates the boundaries between the personal and faceless, the authentic and inauthentic existence of a man.

\section{Ontological Characteristics of the Instrumental Space}

To reach the understanding of the essence of instrumental space as ontological modus of human being, we shall turn to Heidegger's analysis of the notions of instrument and instrumentality, which he did in his famous report The Question Concerning Technology. Heidegger framed the questions, which, in his opinion, need answers foremost: is an instrument a means? What is instrumental itself? What is the relationship between instrumentality and technology? Is modern technology a human activity? Is it possible to reduce Enframing (Gestell) to a system of instruments (equipment)? These questions and answers are our guiding stars in quest of the instrumental space's main traits as the ontological modus of human being.

The definition of technology as a means (instrument) used by people to achieve their goals is anthropological or instrumental, according to Heidegger. He considered his definition correct but stressed that it does not reveal the actual essence of technology, does not provide a real comprehension of "Within what do such things as means and end belong? And what is the instrumental itself?"11 Untangling these questions, the German philosopher writes that the essence of technology as a means will be revealed if we consider the instrumentality through the unity of the four causes..$^{12}$ Although we know that the doctrine of causality goes back to Aristotle, Heidegger notes that his understanding of causality has a different meaning. Namely, he sees cause as 'responsibility for something else'. The three types of causality are: the material (out of which a product made), its (eidos) image and its purpose relate to the product itself. Heidegger calls the fourth type the 'master of the art' as the fourth cause for its discretion regarding the first three causes brings them together. From the master, they start, and through him, they reach the final readiness of the product. Understanding causality in this sense reveals the essence of instrumentality, which, in Heidegger's words, stands on causality. The four kinds of causality in their unity allow something that is not visible to come to presence through the product as an inducing to go forward (Ver-an-lassen). Instrumentality, on the other hand, is a trait of technology, the essence of which involves revealing

\footnotetext{
${ }^{11}$ Martin HEIDEGGER, The Question Concerning Technology, The Question Concerning Technology and Other Essays, Translated and with an Introduction by William Lovitt, NY\&London, Garland Publishing Inc., 1977, 6.

${ }^{12}$ Ibidem.
} 
what is concealed. In this sense, it functionally connects with affirmation on supplying manufacture, which essentially differs from inducing to go forward through bringing-forth (Her-vorbringen). Everything that is disclosed through the supplying production Heidegger calls the standing-reserve (Bestand). The standing-reserve enjoys the status of a fundamental concept as it is connected with the conception of Enframing (Gestell). According to the philosopher, Enframing (Gestell) is nothing technological, nothing on the order of a machine. Enframing (Gestell) is the way of revealing, bringing reality into appearance. Heidegger returns to the question of the extent to which man participates in this revealing. The thinker concludes that man does not precisely dispose of the unconcealment; he merely responds to the addressed challenge; moreover, man often becomes involved in the Enframing (Gestell). Heidegger stresses that a man's ontological status depends on his awareness of this involvement. "As the one who is challenged forth in this way, man stands within the essential realm of Enframing." ${ }^{13}$ Heidegger emphasizes that a man's ontological status depends on how aware they are of this involvement. The disclosure of the secret way of supplying production closes the way for a person to reveal reality through bringing-forth (Her-vorbringen).

Therefore, Heidegger sees the main danger not so much in the external threat of the use of technology for the destruction of humanity but rather in the threat internal for the man himself, who is more and more immersed in the way of revealing the hidden, imposed on him by the Enframing; and this way an individual can take for the only possible way of the existence, perceiving it as an authentic existence. Heidegger gives an example of the Rhine River, the old wooden bridge, and a hydroelectric plant on the Rhine. This example clearly shows the demarcation between the agent of revealing and the unconcealment of what is hidden through bringing-forth. "The hydroelectric plant is not built into the Rhine River as was the old wooden bridge that joined bank with bank for hundreds of years. Rather, the river is dammed up into the power plant."14 The difference lies in the collecting origin of that installation that we address as a challenge. It focuses a person on the supplying production in which he or she loses the original essence, the individual autonomy, dissolving in the faceless system of standing-reserve (Bestand). A different matter is the gathering origin manifesting in the master's ability to build a bridge linking the banks of a river. We may describe such a gathering as 'careful', a master - as a craftsman, and the means (instruments) as 'readiness-to-hand'.

The installation of man on the supplying production also manifested itself in the emergence of exact natural science as a kind of calculating thinking,

\footnotetext{
${ }^{13}$ Martin HEIDEGGER, The Question Concerning Technology, The Question Concerning Technology and Other Essays, Translated and with an Introduction by William Lovitt, NY \& London, Garland Publishing Inc., 1977, 24.

${ }^{14}$ Ibid., 16.
} 
which gave rise to the deceptive appearance that modern technology is applied science. However, Heidegger asserts, there are opposite relations. Contemporaries and followers of Heidegger's fundamental ontology called him a pioneer in the Praxis tradition. "Heidegger is foremost amongst the twentieth-century philosophers who reflected critically on technology," of the German thinker's work by the famous Indian philosopher and critic Koshy Tharakan. He agrees with Heidegger that the context of an instrument leads to the environment and with it to the world. The willingness to use an instrument eventually leads to the fact that Dasein 'for whose sake' also has the structure of following the instrument. According to Tharakan, this experience happens both 'without' and 'inside' science. Thus, 'technology' should not be perceived as 'applied science,' 'technology is wider than explicit science'. "The Heideggerian inversion', effected by the 'tool' analysis, makes a fundamental move in ontology as it makes 'readiness-to-hand' as the basic ontological category by which entities are defined as they are 'in themselves'. It is only when the 'tool-hood' is broken that the 'readiness-to-hand' turns into a 'present-athand' entity amenable to a sort of 'theoretical' knowledge," - wrote the Indian philosopher. ${ }^{16}$

In the last quarter of the $20^{\text {th }}$ century, the issue of the relationship between science and technology is becoming mainstream in both continental and American philosophy of science, which is increasingly starting to follow a phenomenological strategy. An existential-hermeneutic direction emerges, which considers practical experience as the initial one, and technology as an exact embodiment of science in an instrument. This approach, whose representatives call themselves body philosophers ${ }^{17}$, is known as the 'school' of instrumental realism (H. Dreyfus, M. Heim, G. Rose, D. Ihde, and others). ${ }^{18}$ According to D. Ihde, an instrument constitutes not only scientific objects but also objects of the human lifeworld, mediating their self-comprehension. Ihde includes the instrumental world and 'man world' relations as components of the life world of any culture into existential practice as a fundamental level of existence. He emphasizes the importance of Heidegger's 'instrumental analysis' for the further development of the philosophy of technology. Ihde defines an instrument as an interface between man and the world. He describes the 'Self-instrument-world' (Human-machine - World) relations as embodiment relations. ${ }^{19}$ Ihde divides the embodied relations into microperceptual and macroperceptual. The former

\footnotetext{
${ }^{15}$ Koshy THARAKAN, Questioning the Body: From Technology Towards a Sense of Body, Kritike, 5 (2011) 2, 114.

${ }^{16}$ Ibid., 116.

${ }^{17}$ Don IHDE, Instrumental realism: The Interface Between Philosophy of Science and Philosophy of Technology. Bloomington and Indianapolis, Indiana University Press, 1991, 68.

${ }^{18}$ Olga E. STOLYAROVA, Instrumental'nyj realizm D. Ajdi [Ihde's Instrumental Realism], Istoriya filosofii, 5 (2000) 119.

${ }^{19}$ Don IHDE, Technics and Praxis, Boston - London, Reidel Publishing Company, 1979, 6-8.
} 
belongs to the sensory-bodily sphere of human existence; the latter connects with the functioning of the objects of the lifeworld. Each instrument, according to Ihde, acquires its essence from the functional role and actual existence, thus expanding the pragmatic context of human existence with its factuality.

Thus, based on the analysis of the instrument and instrumentality in the philosophy of M. Heidegger, his followers, and critics, we will try to highlight the characteristics of the instrumental space as the ontological modus of human existence. We may call constitutive traits of the instrumental space causality, objectivity (both in the form of standing-reserve (Bestand) and of a work of art), functionality, factuality, coherence, as well as inclusion in existential practice as a fundamental human attitude to things in the form of readiness for work. The difference between the supplying production and the master's works lies in the assembling origin that addresses and challenges man. In readiness to follow an instrument, Dasein also has a structure for following it. If a person perceives his being in the way of supplying production as his own, then the instrumental space becomes almost the only way to implement it. In this case, the instrumental space exerts pressure on the existential possibilities of the existential space replacing more and more personal origins with the system - the boundary between the personal and faceless, authentic and inauthentic existence shifts towards the latter.

The relationship between existential and instrumental spaces has an ontological and historical dimension, manifesting itself in the features of a particular culture. In the last quarter of the $20^{\text {th }}$ century, instruments appear that qualitatively change the reality, pushing its horizons and, at the same time, the relationship between existential and instrumental spaces.

The game-breaking moment is the emergence of computers as a means of constructing the object world and information environment, as a field and a product of information technology application. The emergence of computers was like the birth of a new reality, a new object environment, a new sphere of human activities, and accompanying meanings and senses in the dynamics of comprehension of everyday life. Aside from that, computer networks started performing additional, non-specific functions, for instance, becoming an instrument of confirmation of the existence of many manifestations of objective reality, including self-affirmation. A renowned Spanish researcher of modern civilization processes Manuel Castells notes that the concept of virtual computer reality turned out to be a key in understanding the meaning of information epoch in general and its aspects: social, political, anthropological, psychological, technological, and others. 


\section{Cyberspace and Computer Virtual Reality: New Ontological Realities}

The term cyberspace burst into scientific discourse from the thoughts of the famous fiction writer William Gibson while he was trying to find a new idea for creativity. For the first time, he used the concept in the 1982 novel Burning Chrome, then popularizing it in his Neuromancer novel in 1985. Gibson was looking for a new arena for fantastic action that could compete with space and starships, which were the main venue for the sci-fi writers of his time. The concept of cyberspace came to him unexpectedly. Gibson once was sitting with his yellow notepad, drumming on it with a pencil, and was writing the supposed titles of a new place for his characters' actions: infospace, data space, and cyberspace emerged as the third. The word seemed weird, but, according to Gibson, 'cool', so he chose it. Gibson picked the term basing on a feeling: it sounded like something, as if having a meaning, yet remaining mostly void inside. Gibson called his finding a 'vague neologism'. 'Vague neologism' and the entanglement of an idea that's how the writer rated his chances for future creative works. Gibson says:

"I took my neologism and that vague chain of associations to a piece of prose fiction just to see what they could do. But I didn't have a concept of what it was, to begin with. I still think the neologism and the vague general idea were the important things. I made up a whole bunch of things that happened in cyberspace, or what you could call cyberspace, and so I filled in my empty neologism." ${ }^{20}$

Gibson's neologism carried on in the academic discourse.

The idea of human-computer network interactions surfaced in the 1970s in experiments conducted at Massachusetts Institute of Technology. American journalist and researcher Francis Hamit refer to these in his book Virtual Reality and the Exploration of Cyberspace (1993), who at the time was developing new information technologies. Using computers, according to Hamit, required learning a new culture rather than a new language. He defined virtual reality as "linking computer graphics to human-computer interaction." 21 Thanks to the technology of virtual computer reality, he notes, it has become possible to turn a two-dimensional image into three-dimensional reality management. The idea of possibility and productivity of using virtual objects as substitutes for real-world objects turned out to be a breakthrough. On the one hand, it discovered a new direction of academic and practical research. On the other, it ensured the perception of human-computer interaction methodologically

\footnotetext{
${ }^{20}$ William GYBSON, About the Emergence of 'Cyberspace' (15.06.2011) https://cyberpunkworld. net/news/uiljam_gibson_o_vozniknovenii_kiberprostranstva/2011-06-25-126 (19.12.2019).

${ }^{21}$ Francis HAMIT, Virtual Reality, Vozmozhnye miry $i$ virtual'nye real'nosti [Possible Worlds and Virtual Realities], Translated by A. Dzyubenko. Moscow, Institut snovidenij i virtual'noj real'nosti, 1995, 39-40.
} 
as necessary, feasible, allowing every participant to take advantage. Odds for using virtual computer objects for solving human-set tasks, first of all, consists in high-level flexibility and of exceptional variability, because by changing software, a person may arbitrarily, according to the content and by the peculiarities of the tasks, shuffle the properties, functions, characteristics of virtual objects, manage them. As "people mastered the programs of a new reality, a feeling of inspiration and ease of handling the computers came to them, which gave rise to an effect called flow." 22 Digital information paved the way for almost limitless possibilities of manipulations. Cyberspace and virtual computer reality turned into new spheres of force application in which single academics, research university laboratories, and corporations are competing with each other. American philosopher Michael Heim outlines in The Metaphysics of Virtual Reality (1993) his understanding of cyberspace echoing that of W. Gibson and F. Hamit. To Heim, cyberspace is an extensive computer network where virtual realities coil, it is a set of oriented points by using which we make our way through an incredible amount of information. M. Heim emphasized, when entering cyberspace, one shall outline a mental map of controlling the electronic network, without which the search for the needed information may take an unacceptably long time or may not be productive at all. ${ }^{23}$ Therefore, Heim considered the 'internally imaged sense of the data topology', a vital component of comprehension and action. He argued that the inner map we create for ourselves, combined with the software, is cyberspace. ${ }^{24}$

In the early 1970s, American academic in the field of computer systems theory Frederick P. Brooks (The University of North Carolina at Chapel Hill) made an essential step in the development of computer graphics, creating a panoramic display that allowed a person to navigate in the graphical space with a simple turn of the head. F. Brooks led the development of operating systems for several decades, introduced the term computer architecture into the scientific community, and made a historically significant contribution to the development of software engineering. His book The Mythical Man-Month. Essays on Software Engineering has gained worldwide popularity. ${ }^{25}$

Another American specialist in computer technology Myron W. Krueger, since 1969 has created many interactive computer environments. His achievement was to ensure free and multi-sensory participation in computer events. Krueger discovered an interesting fact. He was surprised that the technically unprepared people perceived the projected reality as ordinary reality. The computer image of themselves was recognized by the 'participants of the event' as their dimension. The same thing was happening to them as to their images.

\footnotetext{
${ }^{22}$ Ibid., 41.

${ }^{23}$ Michael HEIM, The metaphysics of virtual reality. NY, Oxford University Press, Inc., 1993, 133.

${ }^{24}$ Ibidem.

${ }^{25}$ Frederick P. BROOKS, The Mythical Man-Month and Other Essays on Software Engineering, NY, Addison-Wesley Professional, 1995.
} 
They claimed to sense the image as their bodies. If Krueger put an unknown image over their own, they exerted suspicion and avoided contact. ${ }^{26}$ These observations led the scientist to explore and create a video dimension that people could enter from different points to interact with each other actively and graphic 'creations'. Krueger called such experiences artificial reality or interactive experience. In his opinion, an interactive experience opened up new horizons to explore themselves and the adaptive possibilities of perception as part of active human behaviour in an interactive environment. "From the beginning, I wanted to establish an interdisciplinary facility in which to develop the medium, and to ensure that it was applied to aesthetic, scientific, and practical ends simultaneously", Krueger stressed. ${ }^{27}$ M. Krueger highly appreciated the role of computer graphics in the development of information technologies. Although these are expensive technologies, he wrote, they will become the norm shortly. "As one who has worked in three-dimensional graphics for years, I can say that the opportunity for this technology is enormous, particularly for consumer applications", he noted.$^{28}$ According to him, the worlds that will be created with the help of computer technology will be able to reveal more deeply and accurately the properties of the surrounding world, as new ways of visualizing our knowledge about natural forces will be created. Krueger speaks on the differences among the laws of the new reality and the physical laws of the reality in which we live. He notices ironically: "We like to say we invent them, but in fact they are there, waiting to be discovered. When I look at a powerful new technology, I see it as an expression of natural laws, a new vocabulary, and a new syntax added to humankind's repertoire." ${ }^{29}$ The emergence of interactive media by Krueger meant a new stage in computer technology development, i.e., a transition from human interaction with computer events to active participation.

Many Russian authors also define cyberspace as the event-object space of a computer network [30]. ${ }^{30}$ Still, there is another approach that describes it as a space of codes representing arrays of information (databases, packages communication, web-designers, and others). An example of such approach is the definition coined by the American philosopher D. Koepsell:

\footnotetext{
${ }^{26}$ Myron W. KRUEGER, Artificial reality II. NY, Addison-Wesley Professional, 1991, 24.

${ }^{27}$ Ibid., 64.

${ }^{28}$ Ibid., 76.

${ }^{29}$ Myron W. KRUEGER, Artificial reality II, NY, Addison-Wesley Professional, 1991, 264.

${ }^{30}$ Maksim A. PETLIN, Social'no-filosofskie aspekty kiberprostranstva [Social-Philosophical Aspects of Cyberspace], Vestnik Omskogo universiteta, 3 (2014) 78-90; Tatiana A. KIRIK, Virtual'naya real'nost' $i$ ee ontologicheskie prototipy [Virtual Reality and Its Ontological Prototypes]. Kurgan, Izd-vo Kurganskogo gos. un-ta, 2007; Lyudmila V. BAEVA, Virtualizaciya zhiznennogo prostranstva cheloveka i problemy igrovoj internet-zavisimosti (IGD) [Virtualization of Human Life Space and Problems of Game Internet Dependence (IGD)], Filosofskie problemy informacionnyh tekhnologij i zhiznennye praktiki cheloveka, 1(11) (2016) 8-19; etc.
} 
"Cyberspace is a medium composed of silicon chips, copper wires, magnetic tapes and disks, fiber optic cables, and every other component of computers, storage media and networks which stores, transmits and manipulates bits." 31

The considered points of view differ in the research perspectives. In one case, the technical and technological aspects of cyberspace research are emphasized, in the other - socio-cultural, epistemological, and psychological. This situation of interdisciplinary dissociation shows that there is not yet a single problem field of cyberspace research. There is a single academic community holding discussions and dialogues, for which there is not yet a sufficient systemic general theoretical and methodological basis. Cyberspace is the subject of study of different fields of knowledge: theory of computer engineering and technologies, software engineering, cybernetics and informatics, sociology, anthropology, psychology, etc. This necessitates the development of a convergent approach, a new methodology linking technical terms with significant problems of human existence.

Summing up the consideration of approaches and points of view, we can propose a generalizing definition: cyberspace is a concept widely used in technical, information technology and humanities sciences to denote objects, events, processes, algorithms, programs created with the help of large databases (Big Data), which exist and are deployed within virtual computer reality (so to speak 'inside' the computers and computer networks).

Modern cyberspace is characterized by:

- lack of geographical localization (computer events and processes are transboundary. They do not take place in particular cities and countries where computers and servers are, and software developers or session participants live or work).

- Intersubjectivity (computer developments and processes today are often the results of joint parallel networking of many participants).

- Partial anonymity (at this stage, it is difficult or impossible to identify subjectively part of cyberspace).

- Polyfunctionality (it affects all spheres of social life).

- Super-dynamism (extremely fast-changing, information unfolding); represents a type of rapidly growing system (a kind of expanding information universe).

- Temporal multi-vector (ensuring presence here and now, as well as in various sections of the past and possible future).

\footnotetext{
${ }^{31}$ David R. KOEPSELL, The Ontology of Cyberspace: Philosophy, Law, and the Future of Intellectual Property, Chicago, Open Court, 2000, 126.
} 
- Relative independence (under the condition of material resource provision) can generate new micro and macro events without purposeful human influence).

By creating an event (trigger) that starts a flow, a person changes the fabric of being of cyberspace, shifting the traditional models of perception of the spatial and temporal image of the real world, generating a multitude of seemingly contradictory, mutually exclusive streams of perceptions and impressions. Traditional models of perception, within the framework of which processes of adaptation and socialization of an individual were carried out for a long time and which are fixed in language, behavioral models, values and traditions, mores and rituals, suddenly, within the limits of one or two generations, came into motion, creating illusions of a plurality of objective worlds, as well as a plurality of subjective realities in every person. There is a significant transformation of personal perception of many previous constants of existence: space, temporality, body, forms of communication, and so on. These fundamental existential vectors of the human attitude to the world should be defined, set, socially normalized, and fundamentally evaluated.

Cyberspace in the contemporary world seemingly pulls the rope of reality. Many forms of daily living activities are already inextricably linked with and through computers. This often concerns the problem of identity, which is present today in electronic systems through profiles. If a person is not in virtual reality, there is no profile in a social network, there is no author's entry in a digital library, there are no identification numbers in the bases of scientific systems. There is no personality itself, and the author does not exist, his works cannot be found, his merits cannot be attributed to a real person. Existence in virtual computer reality nowadays sometimes becomes more important than factual existence in the world.

"Cyberspace supplants physical space. We see this happening already in the familiar cyberspace of on-line communication - telephone, e-mail, newsgroups, and so forth. When online, we break free, like the monads, from bodily existence. Telecommunication offers an unrestricted freedom of expression and personal contact, with far less hierarchy and formality than are found in the primary social world". ${ }^{32}$

As the computer virtual world seizes us with new possibilities, the usual existential experience in physical reality will narrow its limits.

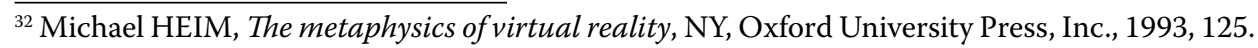




\section{Conclusion}

Virtual computer reality is an exclusive, artificially created world, entrance to which is possible utilizing specially designed technical devices. At the same time, once established, the objects of this world can continue to exist and become real, including the creation of material objects in everyday reality. Thus, virtual computer reality, being an artifact of human thinking and informationtechnological creativity, can significantly - and in the presence of Internetnetworks - massively have a large-scale impact on the content of thought, forms of behaviour of people, their models of feeling, perception of reality and many other processes. Alternately appearing in the field of a contemporary's consciousness, the actual and virtual computer realities compete with each other, creating a contradictory ontological situation. The intensity and duration of stay in this or that reality become a factor confirming its authenticity, originality, importance, and, paradoxically, its realism.

As a basic methodological construction of research of contradictory relations between physical and artificial realities, we suggest considering existential space as an initial integral structure, authentic to the human being. Instrumental space and cyberspace represent stages of development of the objective being, which have both common features and differences. Common features are that both types of objectivity are involved in the Enframing (Gestell) and serve the supplying production, expanding the totality of cultural artifacts, increasing the state of standing-reserve (energy and information). The difference manifests itself in the variety of functionality, degree of inclusion in everyday reality, and the factor of generation. Portability is a trait of a virtual computer environment, indicating its artificial character, nodding at computer means by which it is constructed. If people generate technology (with instrumentality being its trait) as the first stage of mediated human attitude to the world, then computer virtual environment 'generates' cyberspace (unity of human and computer network). Thus, there is a phenomenon of double mediating human attitudes to physical reality. The ontological modus of cyberspace is presented as a modification of instrumental space and existential practice with new content, tasks, and choice of directions of development of the human being and humanity's existential project. Existential space, interacting with cyberspace, on the one hand, pushes the boundaries of the human lifeworld and deepens the self-knowledge, on the other hand, it is as if personally immersed in an impersonally organized system. At the same time, the boundaries of the existential space's basis are narrowing, becoming fragile, personally unprotected. Generally, the existential space, immersed in virtual computer reality, may disappear, being erased with a single click of the mouse. This is the problem of the future, and we are at the dawn of its exploration. 


\section{Lubov E. Motorina* - Veronica M. Sytnik*** \\ Egzistencijalni, instrumentalni kibernetički prostori kao ontološki modusi ljudskog bića \\ Sažetak}

Kontekst i važnost istraživanja: sve je teža zadaća način razvitka općih teorijskih osnova i metodologije ontologijskih problema vezanih uz međudjelovanja i međuodnose između internetskog prostora i fizičkog svijeta, otežan uspostavom računalnog virtualnog okružja, određenog kako prisutnošću ljudskog bića u računalnoj mreži tako i prisutnošću računalne mreže u životu ljudskog bića. Virtualna stvarnost već je, čak u svom razvijenom obliku, široko prepoznata i opisana u akademskim vrelima. Već ima prijedloga za njenu primjenu u medicini, odgoju i obrazovanju, profesionalnom uvježbavanju, svemirskoj, vojnoj, umjetničkoj, automobilskoj industriji, brodogradnji, prometu, zabavi, savjetodavnom pomaganju stanovništvu, administraciji i drugim područjima upravljanja. Prema akademskim predviđanjima usmjeren, raznoliko snažan, razvitak virtualnog računalnog okoliša na širokoj osnovi nastavit će se i u 21. stoljeću. Cilj je ovog proučavanja provesti sustavnu analizu pojmova: egzistencijalni prostor, instrumentalni prostor i kibernetički prostor, kao metodologijsku pripravu za njihove ontologijske moduse: instrumentalni prostor i kibernetički prostor; odrediti (definirati) ontološke značajke instrumentalnog prostora i kibernetičkog prostora, njihove zajedničke oznake (povezanost) i razliku; otkriti egzistencijalne crte uronjenosti osobe u računalnu virtualnu stvarnost - proces emocijalnog percipiranja egzistencije $u$ informacijskom polju - u umjetno stvoreni svijet »ljudi i stvari«, kao i subjektivno-osobne učinke koji prate taj proces. Iskorištena metodologija: analitika Tubitka (Dasein) M. Heideggera, instrumentalni realizam D. Ihdea, na sustavima zasnovan pristup, poredbena analiza. Glavni rezultati: stvaranjem kibernetičkog prostora i virtualne računalne stvarnosti razotkrilo se novo stanje u oblikovanju egzistencijalnog iskustva i zacrtalo sustav tehnološke informacije i socio-psiholoških mjerodavnosti (osposobljenosti). Nužna je sustavna razrada pojmovnog i kategorijalnog aparata. Istraživač će to iskoristiti da opiše ontološke moduse i nove (virtualne, računalne) stvarnosti, te povezanost među njima.

Ključne riječi: bit tehnologije »uokvirivanja« (Gestell), egzistencijalno iskustvo, instrument, kibernetički prostor, ontologija, računalna virtualna stvarnost, tehnologija.

(s engl. prev. Josip Balabanić)

\footnotetext{
* Prof. dr. sc. Lubov E. Motorina, Nacionalno istraživačko sveučilište, Odsjek za filozofiju Moskovskoga zrakoplovnog instituta; adresa: A-80, ГСП-3, 4 Volokolamskoe shosse, 125993 Moskva, Rusija; e-mail: lubov-motorina@yandex.ru.

**:Doc. dr. sc. Veronica M. Sytnik, Nacionalno istraživačko sveučilište, Odsjek za filozofiju Moskovskoga zrakoplovnog instituta; adresa: А-80, ГСП-3, 4 Volokolamskoe shosse, 125993 Moskva, Rusija; e-mail: sytnikvm@gmail.com.
} 